Received: January 21, 2018 | Accepted: February 18, 2018

\title{
HISTORICAL ARCHAEOLOGY IN MAGNA GRAECIA: FROM AN AMERICAN PERSPECTIVE TO THE GREEK COLONIZATION IN SOUTH ITALY*
}

Airton Pollini ${ }^{1}$

\begin{abstract}
The historical archaeology approach was forged for the study of the American society after the European conquest of colonial lands in the new continent. Interested in the comparison between material culture and written records, it was opposed to Prehistory and Anthropology with their methods of inquiry. Its main proposal is to use all available data, material and written, independently, without any hierarchy, but in close comparison. As such, this perspective studies the archaeology of individuals "without history", such as Natives, slaves, women, or even the African diasporas in America, in antagonism to the white male European colonist. Issued from an explicit postcolonial background, this approach may give an important contribution to the study of other ancient societies where interpretations are based on discussions between archaeological remains and texts, such as the Greek colonial communities in Magna Graecia.
\end{abstract}

\section{Keywords}

Postcolonialism; historical archaeology; Palmares; Presidio San Francisco in California; Magna Graecia; Sybaris; Amendolara.

\footnotetext{
* This paper is a revised and developed version of the oral conference given at the Graduate seminar Postkoloniale Antike? Alterität in den Altertumswissenschaften, University of Basel, $4^{\text {th }}$ and $5^{\text {th }}$ December 2017. I shall acknowledge several questions and observations during the discussion in Basel (Switzerland), especially those by Prof. Dr. Tonio Hölscher and Prof. Dr. Christoph Ulf, to whom I am very grateful.

1 Assistant Professor, University of Haute-Alsace, Mulhouse, France. E-mail: airton.pollini@uha.fr
} 


\section{Resumo}

A abordagem da Arqueologia histórica foi forjada para o estudo da sociedade americana após a conquista europeia das terras coloniais no novo mundo. Interessada na comparação entre cultura material e registros escritos, opôs-se à Prehistória e à Antropologia e aos métodos de pesquisa dessas disciplinas. Sua principal proposta é usar todos os dados disponíveis, materiais e escritos, independentemente, sem qualquer hierarquia, mas em estreita comparação. Como tal, esta perspectiva estuda a arqueologia dos indivíduos "sem história", como indígenas, escravos, mulheres, ou mesmo as diásporas africanas na América, em antagonismo com o colonizador masculino e branco. Proposta a partir de um contexto pós-colonial explícito, esta abordagem pode dar um importante contributo para o estudo de outras sociedades antigas para as quais as interpretações se baseiam em discussões entre restos arqueológicos e textos, como as comunidades coloniais gregas na Magna Grécia.

\section{Palavras chave}

Pós-colonialismo; Arqueologia histórica; Palmares, Presidio San Francisco na Califórnia; Magna Grécia; Síbaris; Amendolara. 
Postcolonial theories have become quite popular and accepted in several disciplines, as they were in the beginning developed in a domain called "cultural studies". It is clear that the term, and the approach, is intended as a critique, or even a revolt and rebellion against the domination of the West over the rest of the world, and it inherited both from colonial resistance movements and from the forms of speech that they have generated ${ }^{2}$.

Specifically related to Greek colonization, the main debate was raised after the critics put forward since the famous article by R. Osborne. The issue is relatively well-known and concentrates on the Early Greek colonization or, as stressed by recent English-speaking literature, the eradication of the term "colonization" for the Archaic period. In sum, Early Greek mobility would be a matter of individual choice or of small groups that would, in a first moment, live peacefully in a kind of middle ground, where no one ethnic group would be dominant over the others ${ }^{3}$. If the English-speaking bibliography was mainly convinced by the critical arguments raised, on the other hand, this new view, or revisionism, was not well received by other intellectual environments, mainly by Italian and French scholars, within a strong and already long tradition of study of Greek colonization in South Italy, Sicily and South France ${ }^{4}$.

The main common ground of most of those interpretations is, first of all, the critics to a traditional view of "Hellenization", or "penetrazione greca" in Italian, that is to say, the idea of the arrival of Greeks as violent colonists with the extermination or enslavement of all the Natives. Indeed, since the 1960s, Italians and French have been working to highlight several types of interaction and contact between Greek colonists and Natives, including the use of anthropological approaches such as "acculturation", "ethnicity", "cultural transfers", "hybridization" and others to propose more complex, and hopefully more appropriate

\footnotetext{
2 Main authors who developed this notion are Arjun Appadurai, Homi K. Bhabha, Stuart Hall, Ania Loomba, Marshal Sahlins, Edward Said, Gayatri Spivak. See specially: Bhabha, 2004; Loomba, 2005; Sahlins, 1995; Said, 1993; Said, 2003; Spivak, 1999.

3 Osborne, 1998. Several other authors have reinforced those critics: Hall, 2012; Van Dommelen, 1997; Van Dommelen, 2006; Van Dommelen, 2011; Yntema, 2000. For a synthesis of the debate, see Malkin, 2004.

${ }^{4}$ See the special issue of Ancient West and East of 2011, mainly the contributions by Domínguez, 2011 and Greco, 2011. See also Greco, 2009; Greco \& Lombardo, 2010.
} 
interpretations of those process resulting from the establishment of Greeks overseas 5 .

Secondly, and most probably the main improvement of a postcolonial perspective, there is the need to identify situations of cohabitation, of a middle ground, to borrow the expression used in the Greek context by Irad Malkin ${ }^{6}$. One must accept the possible existence of some situations where no side is necessarily more powerful than the other and where a notion such as pre-colonization or proto-colonization could be operational for the understanding of the first phases of contact between Greeks and Natives?.

However, we must be very vigilant when some scholars may be tempted to extend the idea of the middle ground beyond those phases, after the archaic period, or in a generalization of that process of contacts to explain the whole phenomenon of Greek colonization in the Archaic period. This generalization of a peaceful mode of contact disregards the fact that, for the settlement of Greeks overseas, there was a real conquest of land, some of which could be favored or even directly given by local elite. Therefore, even though one should recognize the existence of some cases of alliances made by colonists and local chieftains, described by later ancient authors by the means of a construction of a tradition inputted to the past, mostly in the form of mixed marriage 8 , one must not erase completely the probable majority of cases of sheer violence and military conquest. On the other hand, if part of the Native society, namely the elite, could have alliances with colonists, mostly to reinforce their domination over their own community, a part of the Natives did lose their land, may have been enslaved, and several women might have been forced to marry Greek colonists.

\footnotetext{
5 The annual congress of Tarentum, in South Italy, functioned as a catalyst and promoter of new forms of interpretation of Greek colonization which took into account Native's input in the formation of a new colonial society. See mainly: Atti Taranto 1961, 1961; Atti Taranto 1967, 1967; Atti Taranto 1997, 1997, and more recent contributions on the character of Greek colonization: Atti Taranto 2010, 2010; Atti Taranto 2013, 2013; Atti Taranto 2014, 2014. See our own commentary: Pollini, 2011. See also Riggway, 2004.

${ }^{6}$ Malkin, 2002; Malkin, 2011.

7 See a synthesis by Esposito, 2012. The debate is most concentrated on the first phases of colonization, with the arrival of the first groups of Greeks. See the two volumes of the conference proceedings: Donnellan, Nizzo \& Burgers, 2016; Donnellan, Nizzo \& Burgers, 2016, especially contributions by DE Angelis, 2016; Lombardo, 2016; Osborne, 2016. In our own paper, we point out that the postcolonial approach in Englishspeaking intellectual environment, mostly based on several French philosophers, was developed when those French theories started to be criticized, creating a certain "intellectual apartheid", cf. Esposito \& Pollini, 2016. See also Amaselle, 2008.

8 See a synthesis by Esposito \& Zurbach, 2010.
} 
In a recent development on the study of Greek colonization in France, postcolonial approaches resulted in the adoption, at least for a short period, of a different vocabulary. The transposition of the word "diaspora" for the mobility of the Greeks 9 , conceived in the long run, not only in the Archaic period, but going up to the end of the Hellenistic period, implied in the analysis of all kinds of mobility: not only the permanent installation of Greeks in newly conquered land, but also several other categories that beforehand were considered separately, as mercenaries and soldiers, potters, artists, intellectuals, among others, either established in new Greek cities or in other contexts, such as emporia or in the service of non-Greek communities or kingdoms, in Etruria, in Egypt or elsewhere. However, a broader definition of Greek mobility implies the necessity of explicitly explaining what kind of phenomenon is at stake, individual or group mobility, temporary or permanent, in Greek new establishments or in other contexts.

\section{Historical archaeology}

Besides the general input represented by postcolonial perspectives, Historical Archaeology's approach may provide an important contribution, in highlighting several forms of domination and violence, even in contexts of cultural contacts and mixed societies. Therefore, Historical Archeology ${ }^{10}$ reintroduces the problems of relations of power: between settlers and Natives of course, but also within each of these groups, between elite and poor, between men and women ${ }^{11}$. In this sense, "fluidity", "diversity", but also "conflict", "contradiction", "dominance" and "resistance" are topics highlighted in a postcolonial and postmodern perspective ${ }^{12}$.

Inspired by Anthropology and the Social Sciences 13 , and in opposition to an anthropological approach to Archaeology, this young discipline initially focused on the study of American society formed after the conquest of Europeans. Afterwards, the fields of Historical Archeology

\footnotetext{
9 The word was used as the theme for the exams in order to become a French public school teacher (Agrégation and CAPES): Collin-Bouffier, 2012; Martinez-Sève, 2012; Dana, Lebreton, et al., 2012; Capdetrey \& Zurbach, 2012, see also D'Ercole, 2012; D'Ercole, 2012.

10 Funari, Hall \& Jones, 1999; Hall e Silliman, 2006; Orser Jr, 2000; Orser Jr, 2002.

11 Gosden, 2001; Gosden, 2004; Lyons \& Papadopoulos, 2002; Voss \& Conlin Casella, 2012; Funari, Carvalho \& Domínguez, 2013.

12 Rago \& Funari, 2008.

${ }^{13}$ Orser Jr, 2000 ; Funari, 1999.
} 
have expanded to include other historical contexts, inviting the archaeologist to tackle archaeological remains and texts ${ }^{14}$, in an approach that denies any form of hierarchy between the two types of data ${ }^{15}$. This approach encourages scholars to compare written descriptions with material culture, not to find what one can read, but to tackle those texts and traditions in order to propose more nuanced interpretations.

In this respect, the framework of gender studies has been widely used and can be appropriately transposed into the attention given to the archaeological remains left by any so-called minority social group, in the political sense of the term, that is, all the oppressed fractions of a given society. In this sense, it can be a very interesting means to apprehend not only the categories that are defined by their gender, but more generally, all the categories that define themselves in opposition to the higher layers, to the elite. It is the main sense of the "subaltern voices" approach, which intends to give substance to those voiceless people who left their messages and history encrypted in material culture. Indeed, Homi K. Bhabha ${ }^{16}$ has shown how hegemonic forms of control need repetition and differentiation to be effective, as well as the importance of identifying contexts of ambivalence.

\section{Maroon society of Palmares}

In a movement from America to Magna Graecia, two case studies of colonial contexts of interaction between colonists and other populations may help distinguishing some essential elements in the analysis of other realities in Antiquity.

The example of the maroon society of Palmares is a traditional standpoint for the identity of ancient Black slaves and for the consciousness and affirmation of Black empowerment in nowadays Brazil17. It was a rather

\footnotetext{
14 Funari, 1999: 57; Funari, Zarankin \& Stovel, 2005. See also: Meskell, 2001; Lawrence \& Shepherd, 2006: 71.

15 Small, 1995: 4-5; Small, 1999: 122-136; Dyson, 1995; Johson, 1999. In regard to Classical Archaeology and the ancient Greek world, see: Ober, 1995; Small, 1995.

16 Bhabha, 2004: 29: "Not only is the social bloc heterogeneous, but, as I see it, the work of hegemony is itself the process of iteration and differentiation. It depends on the production of alternative or antagonistic images that are always produced side by side and in competition with each other. It is this side-by-side nature, this partial presence, or metonymy of antagonism, and its effective significations, that give meaning (quite literally) to a politics of struggle as the struggle of identifications and the war of positions".

17 FunariI \& Carvalho, 2005.
} 
important settlement started by runaway slaves that prospered between 1605 and 1695, having up to ten villages and covering a large area in Northeastern Brazil.

Historical archaeology has proven very useful for the construction of a much more nuanced and complex interpretation of the maroon society, that is, the community of freed ex-slaves, which was composed by several categories besides freed African Blacks and including all sorts of people, as Natives and poor White from European background. On the other hand, if maroons could recover freedom from slavery imposed by colonists, it was very far from any idealization one could project: Palmares was ruled by a king, in the reproduction of some of the traditional African modes of organization, including exploitation of lower-class individuals. Material culture combined with the reassessment of written record has shown then an image much more stratified than simply and idealistic Black ex-slaves who recovered freedom.

\section{Presidio San Francisco in California}

Taking another example and following Barbara Voss ${ }^{18}$, we can reinforce the multidimensional nature of contacts between settlers and other populations in California. Firstly, it is necessary to observe the diversity of non-indigenous peoples: this second example, at the "Presidio San Francisco" in California, in addition to the settlers of European origin, $B$. Voss underlines the presence of free Africans (non-slaves) and nonNative Americans coming from other parts of America.

The focus on the archeology of contacts in the colonizing-colonized binary distinction hid the social differences within each of these groups. In some contexts, ethnicity, gender, religion, class, status or age group may have played a dominant role in relation to the colonizing-colonized dichotomy. Moreover, the terms used for social identification convey differentiation. In Spanish California, for example, the term soldier (soldado in Spanish) contains indications not only about occupation, but also gender, age, nationality, colonial status, social rank, class, perspective future economic and physical capacity, in forms that cannot be separated from each other.

It is very interesting to notice the functioning of a caste system, but this system is actually more porous than one might think. In the case of the "Presidio" in California, the caste system allows the existence of a large

18 Voss, 2015. 
number of categories, according to the type of ethnic or racial mixture. It creates a complex hierarchy, in a kind of "pigmentocracy", in which the clearer skin color means a higher rank in the hierarchy. This system is particularly effective in a border context of Spanish rule, where there was almost no settler born in Europe or even who had a parent born in Europe. The caste of "Spanish", already inferior to that of "Peninsular" (born in the Iberian Peninsula), or "Criollo" (son of a European), gave access to almost all the privileges reserved for higher castes and allowed a framework of social ascension to people of indigenous or African descent through mixed background. In addition, the system also allowed caste change, even by simple declaration.

This porosity and diversity of the caste system transformed and was then replaced by the ethnogenesis of a new identity, the Californio. Here, the acknowledgement of the mixed society does not elude those questions of violence or domination and the creation of a new identity, the ethnogenesis, is conceived in a situation where several sorts of relations of power took place at the same time.

At the Presidio of San Francisco, the colonists were themselves the product of colonization. They were the descendants of Mesoamerican Indians and Africans who had been displaced from their lands by colonization and who were later mobilized as a colonizing force in the name of the Spanish crown. Although contact studies have overwhelmingly emphasized the research on Europeans' contact with Natives, the situation in the San Francisco Presidio was not, in fact, atypical.

Archaeology has shown, however, that during the first decades of colonization, the military colonists of the San Francisco Presidio carried out material strategies that minimized the presence of cultural differences within the population, amplifying the impression of a large presence of white Europeans. Comparisons between textual evidence and material culture could then bring out all the nuances and diversity of the colonial establishment.

\section{Sybaris in Magna Graecia}

Once the main theoretical contribution of Historical Archaeology has been established, the example of Sybaris' hinterland in Magna Graecia (Fig. 1) may shed light in the possibilities offered by this approach applied to Ancient colonial contexts. 
The literary evidence on Sybaris largely determines the interpretation and, as regards to the territory of the city, Strabo's description is the most relevant:

"Next in order, at a distance of two hundred stadia, comes Sybaris, founded by the Achaeans; it is between two rivers, the Crathis and the Sybaris. Its founder was Is of Helice. In early times this city was so superior in its good fortune [euthychia] that it ruled over four nations [ethnè] in the neighborhood, had twenty- five subject cities [poleis], made the campaign against the Crotoniates with three hundred thousand men, and its inhabitants on the Crathis alone completely filled up a circuit of fifty stadia. However, by reason of luxury [tryphè] and insolence [hybris] they were deprived of all their felicity by the Crotoniates within seventy days; for on taking the city these conducted the river over it and submerged it."19

In the same sense, the testimony of Diodorus Siculus adds information about the relatively easy granting of sybarite citizenship:

"For lying as the city did between two rivers, the Crathis and the Sybaris, from which it derived its name, its inhabitants, who tilled an extensive and fruitful countryside, came to possess great riches. And since they kept granting citizenship to many aliens, they increased to such an extent that they were considered to be far the first among the inhabitants of Italy; indeed they so excelled in population that the city possessed three hundred thousand citizens". 20

Current research is obviously unable to determine the four nations and twenty-five cities of Strabo's text and the three hundred thousand citizens is a number far exaggerated. On the other hand, from the comparison between literary tradition and material remains, some researchers use the expression of "empire of Sybaris" to speak about its hinterland and its

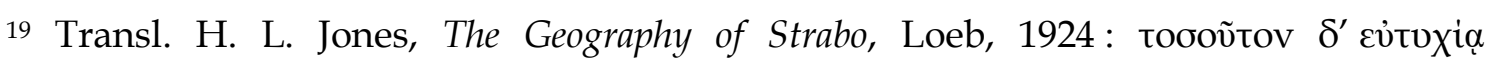

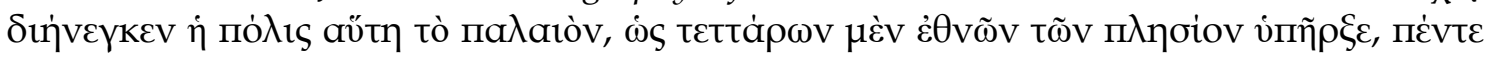

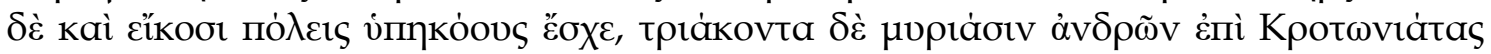

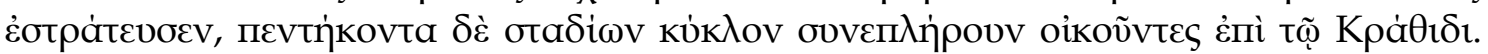

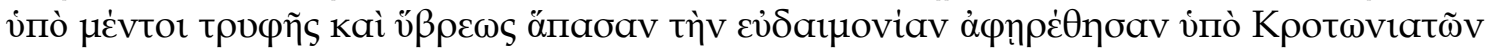

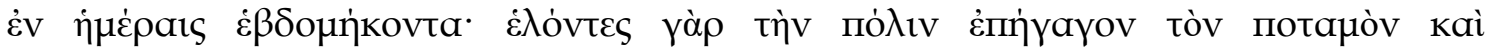

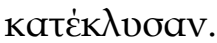

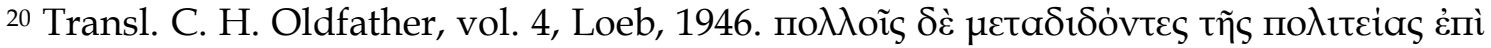

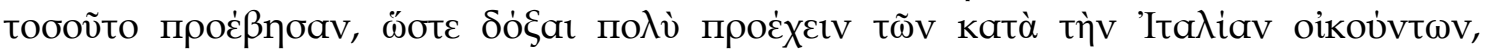

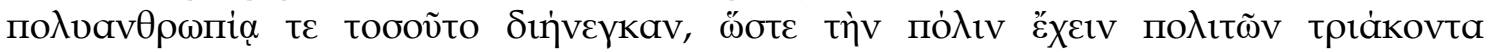
uupıáoas. Cf. Giangiulio, 1987: 28; Camassa, 1988: 639-641; GrecoO, 2013: 199. 
relations with the native people of the territory ${ }^{21}$. M. Bugno ${ }^{22}$ has stressed how the model for this "empire of Sybaris" should be interpreted as comparable to the hegemonic system of the Persian Empire, where dominated communities retained a great deal of autonomy.

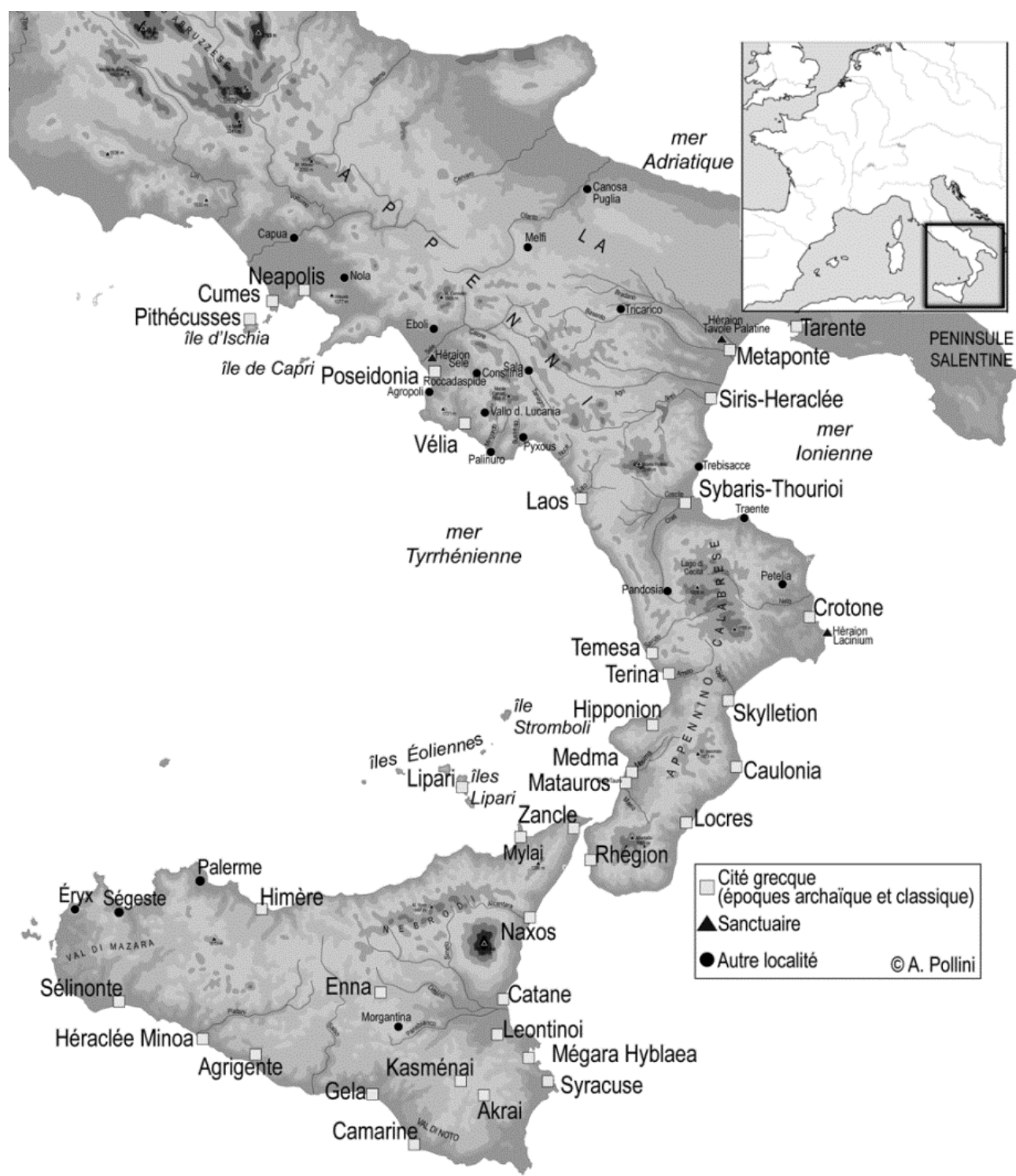

Fig. 1. Map of Magna Greacia and Sicily, with indication of Greek colonial cities. (C) Airton Pollini.

21 GRECO, 1992. See an exegesis of the literary tradition and a historiographical assessment by AVERSA, 2008. See more recently GRECO, 2013.

22 BUGNO, 2001. 
The most important archaeological site of Sybaris's hinterland is Francavilla Marittima, but it is the subject of a large discussion, both in the area of the sanctuary and in the necropolis 23 .

Amendolara (n. 3) 24 is the second most important archaeological site in the hinterland of Sybaris, especially for the analysis of relations between Greeks and Natives. Here the archaeological data depict a reality divergent from that at Francavilla, which reveals the complexity of the situations and the impossibility of defining a single model for the interpretation of these interethnic relations in a colonial context.

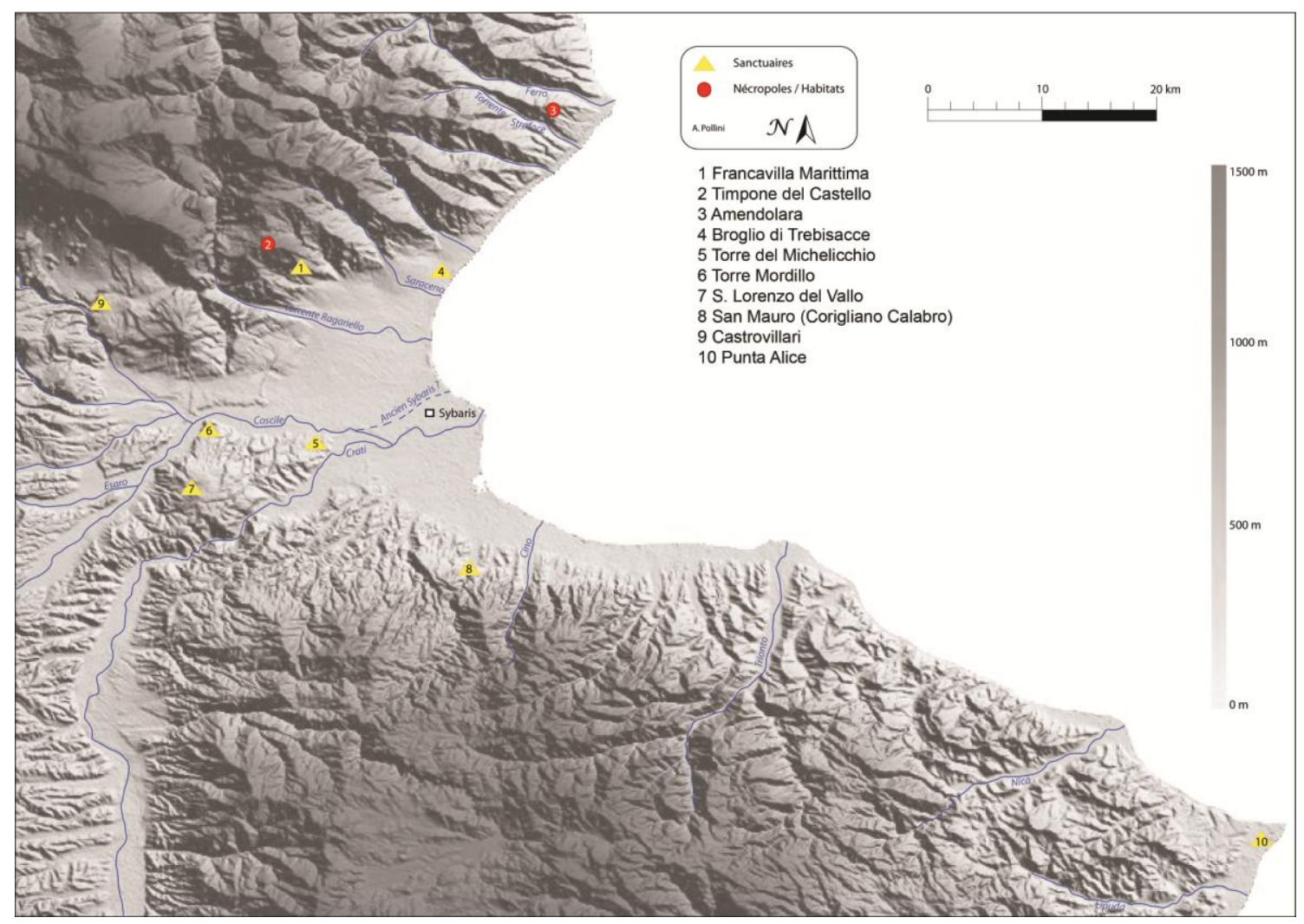

Fig. 2. Map of Sybaris' hinterland, with indication of archaeological sites: Amendolara is number 3. (c) Airton Pollini.

${ }^{23}$ Attema, 2008; Brocato, 2012; Brocato, 2014; Granese, 2006; Granese, 2013; Guggisberg, 2014; Guggisberg, 2016; Gubbisberg, Colombi \& Spichtig, 2012; Kleibrink, Jacobsen \& Handberg, 2004; Kleibrink \& Weistra, 2013; La Genière de, 1989; Luppino, Quondam, et al., 2010; Maaksant-Kleibrink, 2005; Maaksant-Kleibrink, 2006; Paoletti, 2014; Quondam, 2009.

${ }^{24}$ La Genière de, 1984; La Genière de, 2012. The identification of archaeological remains in the town of Amendolara dates from the 1930s, during agricultural work in the region of Agliastroso, cf. Notizie degli Scavi, 1931, p. 654-655 and Notizie degli Scavi, 1939, p. 368-369, quoted by La Genière de, 2012: 9. For a brief synthesis, see Osanna, 1992: 163-164, n. 27. 
Located almost $27 \mathrm{~km}$ from the urban center of Sybaris, Amendolara is composed of two sites with at least two cores each. In the first place, a necropolis can be identified in the locality Agliastroso and a habitat area in Rione Vecchio. These two nuclei show traces of early Iron Age occupation, in a time range from the $9^{\text {th }}$ to the end of the $8^{\text {th }}$ century BCE, with a clear interruption at the end of the $8^{\text {th }}$ century, when the necropolis of Agliastroso was abandoned. Only a few fragments datable to the $7^{\text {th }}$ century indicate a reduced continuity of use of the habitat area at Rione Vecchio after the end of the $8^{\text {th }}$ century.

The second site of Amendolara, located less than $2 \mathrm{~km}$ away from the first, is composed of two areas of necropolis, in Mangosa and Uomo Morto (Paladino), as well as a habitat on the hill of San Nicola. The necropolis was artificially divided in two by the construction of a modern house, and only the Paladino West was systematically excavated between 1967 and 1975, and delivered a total of 329 fully published tombs ${ }^{25}$. The Paladino West chronology starts in the Iron Age and some of the most recent tombs superimpose the oldest, which allowed some hypothesis of family enclosures, although the absence of low walls does not permit affirming it with precision ${ }^{26}$.

The funeral ritual shows little variation during its use and the most common form is that of the pseudo-cist: small side walls composed of irregular slabs surrounding the funerary pit, with a slab standing at the end where the head rested, most often in the west. It is obvious that a necropolis used for two centuries also has numerous anomalies, analyzed in detail by J. de La Genière27.

The funerary ritual of the tombs dated until the beginning of the $7^{\text {th }}$ century is attributed to the Native context and seems reserved for the local elite. From the second half of the $7^{\text {th }}$ century, metal objects, weapons in men's graves and ornaments in women's graves, gradually disappeared and, by the end of the century, the furniture was composed almost exclusively of pottery. The site is then interpreted as a Native group in alliance or in a relation of dependency to Greek settlers.

On the hill of S. Nicola, archaeological research has identified two terraces occupied by houses dated between the first third of the $6^{\text {th }}$ century and the last decade of the century, at the time of the destruction of Sybaris by Crotone, in 511 BCE. On the upper terrace, the houses are

\footnotetext{
${ }^{25}$ La Genière de, 2012.

${ }^{26}$ La Genière de, 2012: 235.

27 La Genière de, 2012: 237-241.
} 
large and follow a given orientation by straight paths or streets. The construction techniques are comparable to the archaic houses of the urban center of Sybaris, found in the site of Stombi ${ }^{28}$. The houses on the lower terrace are not so regular in their orientation, perhaps because of the greater inclination of the slope there. The characteristics of S. Nicola's habitat seem to corroborate the hypothesis of Native settlement whose relations with Greek settlers show a context of alliance or dependence.

The arrival of the settlers at the end of the $8^{\text {th }}$ century caused a first destruction of the indigenous center at Agliastroso and Rione Vecchio, in a similar pattern to the other sites of the territory of Sybaris. On the other hand, the particularity of Amendolara is the persistence of the native element near the original site and reflecting close relationship to Greek colonists. The reorganization of the area after the Greek conquest seems to benefit a part of the native population, as seen in the case of the habitat of S. Nicola.

We can thus propose an interpretation for the particularity of Amendolara. This native settlement is located at a greater distance from the urban center of Sybaris and this remoteness probably implied more difficulty for a direct control of the lands by the Greek colonists. The hold on a larger territory required some form of agreement of the native populations, at least of their elite.

In addition to Francavilla and Amendolara, the other archaeological sites of the territory of Sybaris are relatively poorly known and, for the most part, they are fortuitous discoveries, searched in a limited and unsystematic way ${ }^{29}$. They do not add much for our own purpose and analysis here.

\section{Conclusion}

In our discussion on the theoretical means to apprehend the various forms of interaction between colonists, Natives and other immigrants, a complex problem is to determine the proportion of each ethnic and social group is concerned in a given context. In respect to Amendolara, our case study, how many tombs, how important was the Native occupation of the settlement here? In general, what could be the estimates of the number of Natives living in the area that became the territory of Sybaris? A great input to discussion would be to precise and reliable estimates. They may

28 Cf. Sibari $V, 1992$.

${ }^{29}$ See a synthesis by Luppino, 1996. See also an analysis by Greco, 1992. 
give a certain idea of the necessity of violence in the conquest of arable land that was previously exploited by Natives and that became Greek possession. Accounting that only part of the necropolis at Paladino (West) gave light to a total of 329 tombs distributed in two centuries, the settlement can be considered quite relevant. It seems enough to assert the use of an important degree of violence in the conquest of land, either directly or in a state of dependency, as appears to be the case at Amendolara.

In the absence of more precise quantitative data, our intent was first of all to propose a theoretical framework that may help our interpretations of archaic Greek settlements progress. Therefore, Historical Archaeology perspective may be transposed from American modern contexts to Classical Antiquity. In this sense, we tried to show, firstly, how complex ancient situations may have been. Secondly, and this is the main issue, when one introduces a postcolonial perspective to the study of Greek colonization, it is essential to reinforce all the relations of power that it may be at play at the same time. We may now highlight the presence of elements of both Native and Greek backgrounds, to which it is very important to add all other kinds of input, such as other immigrants who also settled in the new Greek cities or populations in different forms of mobility who left important signs of their frequent visits, may they be Etruscan, Egyptian, Phoenician / Carthaginians, or others. Besides the recognition of several forms of cultural interaction, from sheer violence and conquest to some sorts of cohabitation, it is essential to apprehend all forms of relations of power, not only between Greek colonists and Natives, taken as uniform groups, but rather within each group. The distinction is not only ethnic, but it is mainly between higher and lower strata. Examples from Historical Archaeology American sites point out to several intermediary and nuanced categories, and, in the archaeology of Greek colonization, we should look for poor Greek and rich elite Native, as well as all possible intermediary conditions.

\section{References}

Alle origini della Magna Grecia: mobilità, migrazioni, fondazioni. Atti del Convegno di studi sulla Magna Grecia, L, 2010, Tarente: Istituto per la Storia e l'Archeologia della Magna Grecia

AMSELLE, Jean-Loup. L'Occident décroché : enquête sur les postcolonialismes, coll. Un Ordre d'idées, Paris: Stock, 2008. 
ATTEMA, Peter. Conflict or coexistence? Remarks on indigenous settlements and Greek colonization in the foothills and hinterland of the Sibaritide (Northern Calabria, Italy), in BILDE, Pia Guldager \& PETERSEN, Jane Hjarl (eds.). Meetings of cultures in the Black sea region, Aarhus: Aarhus university press, 2008, p. 67-99.

AVERSA, Fabio. Società e politica a Sibari nel VI sec. a.C., Istituto di archeologia e storia antica (Lecce, Italie). Quaderni dell'Istituto di archeologia e storia antica. Università di Lecce, ISSN 0394-5995, 12, 2008, p. 7-47.

BHABHA, Homi K. The Location of culture, coll. Routledge classics, Londres: Routledge, 2004.

BROCATO, Paolo. Verso una rilettura critica degli scavi della necropoli enotria di Macchiabate a Francavilla Marittima (CS). Convivenze etniche, scontri e contatti di culture in Sicilia e Magna Grecia, coll. Aristonothos. Scritti per il Mediteraneo antico, 7, Trento: Tangram, 2012, p. 423-443.

BROCATO, Paolo (ed.). Studi sulla necropoli di Macchiabate a Francavilla Marittima (Cs) e sui territori limitrofi. Ricerche, Supplementi, 5, Arcavacata di Rende: Università della Calabria, 2014.

BUGNO, Maurizio. Strabone VI, 1, 13 C. 263 e l'ỏpxท่ di Sibari, in BUGNO, Maurizio \& MASSERIA, Concetta (eds.). Il mondo enotrio tra VI $e$ $V$ secolo a.C., coll. Atti dei seminari napoletani, 1996-1998, Quaderni di ostraka, 1, Naples: Loffredo, 2001, p. 303-327.

CAMASSA, Giorgio. La codificazione delle leggi e le istituzioni politique delle città greche della Calabria in età arcaica e classica, in SETTIS, Salvatore (ed.). Storia della Calabria. Vol. 1, Storia della Calabria antica, Rome: Gangemi, 1988, p. 613-656.

CAPDETREY, Laurent \& ZURBACH, Julien (eds.). Mobilités grecques. Mouvements, réseaux, contacts en Méditerranée, de l'époque archaïque à l'époque hellénistique. Scripta Antiqua, 46, Bordeaux: Ausonius, 2012.

COLLIN-BOUFFIER, Sophie (ed.). Les diasporas grecques du détroit de Gibraltar à l'Indus, VIIIe siècle av. J.-C.-fin du IIIe siècle av. J.-C. Pour les concours. Série Cours, Paris: Sedes, 2012.

Confini e frontiera nella grecità d'Occidente. Atti del Convegno di Studi sulla Magna Grecia, XXXVII, 1997, Tarente: Istituto per la Storia e l'Archeologia della Magna Grecia, 1999.

D'ERCOLE, Cecilia. L'essaimage colonial grec en Méditerranée antique : espaces, réseaux économiques, interactions culturelles, Annuaire. Comptes 
rendus des cours et conférences, École des Hautes Études en Sciences Sociales, 2010-2011, 2012, p. 290-291.

D'ERCOLE, Maria Cecilia. Histoires méditerranéennes : aspects de la colonisation grecque de l'Occident à la mer Noire, VIII-IVe siècles av. J.-C., coll. Collection Les Hespérides, Paris: Errance, 2012.

DANA, Madalina, LEBRETON, Stéphane, et alii. Les diasporas grecques : VIIIe-III ${ }^{e}$ s., coll. Clefs concours. Histoire ancienne, Neuilly: Atlande, 2012.

DE ANGELIS, Franco. E pluribus unum: the multiplicity of models, in DONNELLAN, Lieve, NIZZO, Valentino \& BURGERS, Gert-Jan (eds.). Conceptualising early colonisation, Contextualising early colonisation II, Bruxelles: Institut historique belge de Rome, 2016, p. 97-104.

DOMÍNGUEZ, Adolfo J. The origins of Greek colonisation and the Greek polis: some observations, Ancient West and East (AWE), 10, 2011, p. 195207.

DONNELLAN, Lieve, NIZZO, Valentino \& BURGERS, Gert-Jan (eds.). Contexts of early colonization. Contextualizing early colonization, 1, Rome: Palombi, 2016.

DONNELLAN, Lieve, NIZZO, Valentino \& BURGERS, Gert-Jan (eds.). Conceptualising early colonisation. Contextualizing early colonization, 2, Bruxelles: Belgisch Historisch Insituut te Rome, 2016.

DYSON, Stephen. Is there a text in this site?, in SMALL, David B. (ed.). Methods in the Mediterranean: historical and archaeological views on texts and archaeology, Leiden: Brill, 1995, p. 25-44.

ESPOSITO, Arianna. La question des implantations grecques et de la précolonisation en Italie du Sud : entre emporia et apoikiai, in MARTINEZSÈVE, Laurianne (ed.). Les diasporas grecques du VIIIe à la fin du IIIe siècle av. J.-C., coll. Pallas, 89, Toulouse: Presses universitaires du Mirail, 2012, p. 97-121.

ESPOSITO, Arianna \& POLLINI, Airton. Post-colonialism from America to Magna Graecia, in DONNELLAN, Lieve, NIZZO, Valentino \& BURGERS, Gert-Jan (eds.). Conceptualising early colonisation, Contextualising early colonisation, II, Bruxelles: Institut historique belge de Rome, 2016, p. 61-75.

ESPOSITO, Arianna \& ZURBACH, Julien. Femmes indigènes et colons grecs : quelques observations, in ROUILLARD, Pierre (ed.). Portraits de 
migrants, portraits de colons, coll. Colloques de la Maison René-Ginouvès, 6, 2, 2010, p. $51-70$

FUNARI, Pedro Paulo Abreu. Historical archaeology from a world perspective, in FUNARI, Pedro Paulo Abreu, HALL, Martin \& JONES, Siân (eds.). Historical Archaeology: back from the edge, Londres: Routledge, 1999, p. 37-66.

FUNARI, Pedro Paulo Abreu \& CARVALHO, Aline Vieira de. Palmares, ontem e hoje, Rio de Janeiro, RJ: Zahar, 2005.

FUNARI, Pedro Paulo Abreu, CARVALHO, Aline Vieira de \& DOMÍNGUEZ, Lourdes (eds.). Arqueología de contacto: diálogos latinoamericanos, Campinas: Unicamp, 2013.

FUNARI, Pedro Paulo Abreu, HALL, Michael \& JONES, Sîan (eds.). Historical Archaeology: back from the edge. One world archaeology, 31, Londres: Routledge, 1999.

FUNARI, Pedro Paulo Abreu, ZARANKIN, Andrés \& STOVEL, Emily (eds.). Global archaeological theory: contextual voices and contemporary thoughts, New York: Kluwer academic/Plenum publishers, 2005.

GIANGIULIO, Maurizio. Aspetti di sotria della Magna Grecia arcaica e classica fino alla guerra del Peloponneso, in PUGLIESE CARRATELLI, Giovanni (ed.). Magna Grecia. 2 Lo sviluppo politico, sociale ed economico, Milan: Electa, 1987, p. 9-54.

GOSDEN, Chris. Postcolonial archaeology: issues of culture, identity, and knowledge, in HODDER, Ian (ed.). Archaeological theory today, Cambridge: Polity, 2001, p. 241-261.

GOSDEN, Chris. Archaeology and colonialism: cultural contact from 5000 BC to the present, coll. Topics in contemporary archaeology, Cambridge: Cambridge University Press, 2004.

GRANESE, Maria Tommasa. Culto e pratiche rituali nel santuario arcaico di Francavilla Marittima (Sibari - CS), Annuario della Scuola archeologica di Atene e delle missioni italiane in oriente, LXXXIV, s. III, 6, t. 1, 2006, p. 417463.

GRANESE, MARIA TOMMASA. Un luogo di culto del territorio di Sibari: il santuario di Francavilla Marittima (CS), in DELIA, Giorgio \& MASNERI, Tullio (eds.). Sibari : archeologia, storia, metafora, coll. Quaderni del liceo, 2, Castrovillari: Il coscile, 2013, p. 57-84. 
Greci e Italici in Magna Grecia. Atti del Convegno di studi sulla Magna Grecia, I, 1961, Tarente: Istituto per la Storia e l'Archeologia della Magna Grecia

GRECO, Emanuele. L'impero di Sibari: bilancio archeologico-topografico. Sibari e la Sibaritide. Atti del convegno di studi sulla Magna Grecia, XXXII, 1992, Tarente, Naples: Istituto per la Storia e l'Archeologia della Magna Grecia, 1993, p. 459-485.

GRECO, Emanuele. Le esperienze coloniali greche : modelli e revisioni: introduzione ai lavori in FRISONE, Flavia \& LOMBARDO, Mario (éds.). Colonie di colonie. Le fondazioni sub-coloniali greche tra colonizzazione e colonialismo, 2009, Lecce: Congedo editore, p. 9-16.

GRECO, Emanuele. On the Origin of the Western Greek Poleis, Ancient West and East (AWE), 10, 2011, p. 233-242.

GRECO, Emanuele. Sul cosiddetto 'impero' di Sibari fino alla tirannide di Telys ed alla distruzione della città, in DELIA, Giorgio \& MASNERI, Tullio (eds.). Sibari : archeologia, storia, metafora, coll. Quaderni del liceo, 2, Castrovillari: Il coscile, 2013, p. 197-203.

GRECO, Emanuele \& LOMBARDO, Mario. La colonizzazione greca: modelli interpretativi nel dibattito attuale. Alle origini della Magna Grecia: mobilità, migrazioni, fondazioni. Atti del Convegno di studi sulla Magna Grecia, L, 2010, Tarente, Naples: Istituto per la Storia e l'Archeologia della Magna Grecia, p. 37-60.

GUGGISBERG, Martin A. The Macchiabate necropolis in Francavilla Marittima (Calabria): some preliminary notes on the recent excavations by the university of Basel, in NIJBOER, Albert, WILLEMSEN, Sarah Lea, et alii (eds.). Macchiabate necropolis in Francavilla Marittima, coll. Caeculus, 8, Leuven: Peeters, 2014, p. 153-167.

GUGGISBERG, Martin A. Local identity and cultural exchange in (pre-) colonial Francavilla Marittima: the Macchiabate necropolis in the light of new excavations, in DONNELLAN, Lieve, NIZZO, Valentino \& BURGERS, Gert-Jan (eds.). Contexts of early colonization, coll. Acts of the conference "Contextualizing early colonization : archaeology, sources, chronology and interpretative models between Italy and the Mediterranean", vol. 1. Papers of the Royal Netherlands Institute in Rome, 64, Roma: Palombi, 2016, p. 237-246.

GUGGISBERG, Martin A., COLOMBI, Camilla \& SPICHTIG, Norbert. Gli scavi dell'Università di Basilea nella necropoli enotria di Francavilla Marittima, Bollettino d'Arte, 97, fasc. 15, 2012, p. 1-18. 
HALL, Jonathan. Early Greek settlement in the west: the limits of colonialism, in BOSHER, Kathryn (ed.). Theatre Outside Athens: Drama in Greek Sicily and South Italy, Cambridge: Cambridge University Press, 2012, p. 19-34.

HALL, Martin \& SILLIMAN, Stephen W. (eds.). Historical archaeology. Blackwell studies in global archaeology, Malden, MA: Blackwell Publishing, 2006.

Ibridazione e integrazione in Magna Grecia: forme modelli dinamiche. Atti del Convegno di studi sulla Magna Grecia, LIV, 2014, Tarente: Istituto per la storia e l'archeologia della Magna Grecia

JOHNSON, Matthew H. Rethinking historical archaeology, in FUNARI, Pedro Paulo Abreu, HALL, Martin \& JONES, Siân (eds.). Historical Archaeology: back from the edge, Londres: Routledge, 1999, p. 23-36.

KLEIBRINK, Marianne, JACOBSEN, Jan Kindberg \& HANDBERG, Søren. Water for Athena: votive gifts at Lagaria (Timpone della Motta, Francavilla Marittima, Calabria), World Archaeology, 36, n. 1, The Object of Dedication, 2004, p. 43-67.

KLEIBRINK, Marianne \& WEISTRA, Elizabeth. Una dea della rigenerazione, della fertilità e del matrimonio. Per una ricostruzione della dea precoloniale della Sibaritide, in DELIA, Giorgio \& MASNERI, Tullio (eds.). Sibari : archeologia, storia, metafora, coll. Quaderni del liceo, 2, Castrovillari: Il coscile, 2013, p. 35-55.

La città e il suo territorio. Atti del convegno di studi sulla Magna Grecia, VII, 1967, Tarente: Istituto per la Storia e l'Archeologia della Magna Grecia, 1968.

LA GENIÈRE De, Juliette. Amendolara, in NENCI, Giuseppe \& VALLET, Georges (eds.). Bibliografia topografica della colonizzazione greca in Italia e nelle isole tirreniche, III, siti Abaceno-Bari, Pisa: Scuola normale superiore, 1984, p. 210-214.

LA GENIÈRE De, Juliette. Francavilla Marittima, in NENCI, Giuseppe \& VALLET, Georges (eds.). Bibliografia topografica della colonizzazione greca in Italia e nelle isole tirreniche, VII, siti Cuccuvà-Garaguso, Pisa: Scuola normale superiore, 1989, p. 492-497.

LA GENIÈRE De, Juliette. Amendolara : la nécropole de Paladino Ouest, coll. Collection du Centre Jean Bérard, 39, Naples: Centre Jean Bérard, 2012. 
LAWRENCE, Susan \& SHEPHERD, Nick. Historical archaeology and colonialism, in HICKS, Dan \& BEAUDRY, Mary C. (eds.). The Cambridge companion to historical archaeology, Cambridge: Cambridge University Press, 2006, p. 69-86.

LOMBARDO, Mario. Le 'prime fondazioni' greche in Occidente : tradizioni antiche e letture moderne, in DONNELLAN, Lieve, NIZZO, Valentino \& BURGERS, Gert-Jan (eds.). Contexts of early colonization, coll. Acts of the conference "Contextualizing early colonization : archaeology, sources, chronology and interpretative models between Italy and the Mediterranean", vol. 1. Papers of the Royal Netherlands Institute in Rome, 64, Roma: Palombi, 2016, p. 261-273.

LOOMBA, Ania. Colonialism-postcolonialism, 2 a ed., Londres: Routledge, 2005.

LUPPINO, Silvana. I Santuari dispersi. Santuari della Magna Grecia in Calabria, coll. I Greci in Occidente, Naples: Electa, 1996, p. 221-224.

LUPPINO, Silvana, QUONDAM, Francesco, et alii. Sibaritide: riletture di alcuni contesti funerari tra VIII e VII sec. a.C. Alle origini della Magna Grecia: mobilità, migrazioni, fondazioni. Atti del Convegno di studi sulla Magna Grecia, L, 2010, Tarente, Naples: Istituto per la Storia e l'Archeologia della Magna Grecia, p. 643-682.

LYONS, Claire L. \& PAPADOPOULOS, John K. (eds.). The archaeology of colonialism, Los Angeles: Getty Research Institute, 2002.

MAASKANT-KLEIBRINK, Madeleine. The early Athenaion at Lagaria (Francavilla Marittima) near Sybaris: an overview of its early-geometric II and its mid-7th century BC phases. Papers in Italian archaeology. 6. Communities and settlements from the Neolithic to the Early Medieval Period. Proceedings of the 6th conference of Italian archaeology held at the University of Groningen, Groningen Institute of Archaeology, the Netherlands, April 15-17, 2003, BAR. International series, 1452, 2005, Oxford: Archaeopress, p. 754772 .

MAASKANT-KLEIBRINK, Madeleine. Oenotrians at Lagaria near Sybaris. A native proto-urban centralised settlement : a preliminary report on the excavation of timber dwellings on the Timpone della Motta near Francavilla Marittima (Lagaria), Southern Italy, coll. Accordia specialist studies on Italy, 11, Londres: Accordia Research Centre, University of London, 2006.

MALKIN, Irad. A colonial Middle Ground: Greek, Etruscan, and local elites in the Bay of Naples, in LYONS, Claire L. \& PAPADOPOULOS, 
John K. (eds.). The archaeology of colonialism, Los Angeles: Getty Research Institute, 2002, p. 151-181.

MALKIN, Irad. Postcolonial Concepts and Ancient Greek Colonization, MLQ: Modern Language Quarterly, vol. 65, n. 3, 2004, p. 341-364.

MALKIN, Irad. A Small Greek World: networks in the Ancient Mediterranean, Oxford: Oxford University Press, 2011.

MARTINEZ-SÈVE, Laurianne (ed.). Les Diasporas grecques du VIIIe à la fin du III siècle av. J.-C. Pallas, 89, Toulouse: Presses universitaires du Mirail, 2012.

MESKELL, Lynn. Archaeologies of identity, in HODDER, Ian (ed.). Archaeological theory today, Cambridge: Polity, 2001, p. 187-213.

OBER, Josiah. Greek Horoi: artifactual texts and the contingency of meaning, in SMALL, David B (ed.). Methods in the Mediterranean: historical and archaeological views on texts and archaeology, Leiden: Brill, 1995, p. 91123.

ORSER Jr, Charles E. Introducción a la arqueología histórica, Trad.ZARANKIN, Andrés, Buenos Aires: Asociación amigos del Instituto nacional de antropología, 2000.

ORSER Jr, Charles E. (ed.). Encyclopaedia of Historical Archaeology, Londres: Routledge, 2002.

OSANNA, Massimo. Chorai coloniali da Taranto a Locri : documentazione archeologica e ricostruzione storica, Rome: Istituto Poligrafico e Zecca dello Stato, 1992.

OSBORNE, Robin. Early Greek Colonization? The Nature of Greek Settlement in the West, in FISHER, Nick \& VAN WEES, Hans (eds.). Archaic Greece: New Approaches and New Evidence, Londres: Duckworth, 1998, p. 251-269.

OSBORNE, Robin. Greek 'colonisation': what was, and what is, at stake?, in DONNELLAN, Lieve, NIZZO, Valentino \& BURGERS, Gert-Jan (eds.). Conceptualising early colonisation, Contextualising early colonisation II, Bruxelles: Institut historique belge de Rome, 2016, p. 21-26.

PAOLETTI, Maurizio. Presentazione. La necropoli enotria di Macchiabate, Lagaria e la 'dea di Sibari', in BROCATO, Paolo (ed.). Studi sulla necropoli di Macchiabate a Francavilla Marittima (Cs) e sui territori 
limitrofi, coll. Ricerche, Supplementi, 5, Arcavacata di Rende: Università della Calabria, 2014, p. 7-21.

Poleis e politeiai nella Magna Grecia arcaica e classica. Atti del Convegno di studi sulla Magna Grecia, LIII, 2013, Tarente: Istituto per la Storia e l'Archeologia della Magna Grecia

POLLINI, Airton. Les congrès de Tarente et les thèmes de recherche sur la Grande Grèce, Mélanges de l'École française de Rome. Antiquité, 123-2, 2011, p. $423-432$.

QUONDAM, Francesco. La necropoli di Francavilla Marittima: tra mondo indigeno e colonizzazione greca, in BETTELLI, Marco, De FAVERI, Cecilia \& OSANNA, Massimo (eds.). Prima delle colonie : organizzazione territoriale e produzioni ceramiche specializzate in Basilicata e in Calabria settentrionale ionica nella prima età del ferro, coll. Atti delle giornate di studio, Matera, 20-21 novembre 2007, Venosa: Osanna, 2009, p. 139-178.

RAGO, Margareth \& FUNARI, Pedro Paulo Abreu (eds.). Subjetividades antigas e modernas, São Paulo: Annablume, 2008.

RIDGWAY, David. The Italian Iron Age and Greece: from Hellenization to interaction. Festschrift in Honour of J. Richard Green, coll. Mediterranean archaeology. Supplement, Sydney: Dept. of Archeology, University of Sydney 2004, p. 7-14.

SAHLINS, Marshall. How 'natives' think: about captain Cook, for example, Chicago: University of Chicago Press, 1995.

SAID, Edward W. Culture and imperialism, New York: Knopf, 1993.

SAID, Edward W. Orientalism, Londres: Penguin, 2003.

Sibari V : relazione preliminare delle campagne di scavo 1973 (Parco del Cavallo ; Casa Bianca) e 1974 (Stombi ; Incrocio ; Parco del Cavallo ; Prolungamento Strada; Casa Bianca). coll. Notizie degli scavi di antichità. Atti della accademia nazionale dei Lincei, 42-43, Roma: Accademia nazionale dei Lincei, 1992.

SMALL, David B. Introduction, in SMALL, David B. (ed.). Methods in the Mediterranean: historical and archaeological views on texts and archaeology, Leiden: Brill, 1995, p. 1-22.

SMALL, David B. Monuments, laws, and analysis: combining archaeology and text in Ancient Athens, in SMALL, David B. (ed.). Methods in the Mediterranean: historical and archaeological views on texts and archaeology, Leiden: Brill, 1995, p. 143-174. 
SMALL, David B. The tyranny of the text: lost social strategies in current historical period archaeology in the classical Mediterranean, in FUNARI, Pedro Paulo Abreu, HALL, Martin \& JONES, Siân (eds.). Historical Archaeology: back from the edge, Londres: Routledge, 1999, p. 122-136.

SPIVAK, Gayatri Chakravorty. A critique of postcolonial reason : toward a history of the vanishing present, Cambridge (Mass): Harvard university press, 1999.

VAN DOMMELEN, Peter. Colonial constructs: colonialism and archaeology in the Mediterranean, World Archaeology, 28, n 3, 1997, p. 305-323.

VAN DOMMELEN, Peter. Colonial matters: material culture and postcolonial theory in colonial situations, in TILLEY, Christopher, KEANE, Webb, et alii (eds.). Handbook of Material Culture, Londres: Sage, 2006, p. 104-124.

VAN DOMMELEN, Peter. Postcolonial archaeologies between discourse and practice, World Archaeology, 43.1, 2011, p. 1-6.

VOSS, Barbara L. The Archaeology of ethnogenesis: race and sexuality in colonial San Francisco, 2 a ed., Gainesville: University Press of Florida, 2015.

VOSS, Barbara L. \& CONLIN CASELLA, Eleanor (eds.). The Archaeology of colonialism: intimate encounters and sexual effects, New York: Cambridge University Press, 2012.

YNTEMA, Douwe Geert. Mental landscapes of colonization: the ancient written sources and the archaeology of early colonial-Greek southeastern Italy, Babesch, 75, 2000, p. 1-49. 